\title{
CYTOCHEMICAL DEMONSTRATION OF PROTEOLYTIC ACTIVITY OF HUMAN AND RAT SPERMATOZOA
}

\author{
L. BENÍTEZ-BRIBIESCA AND SILVIA VELÁZQUEZ-MEZA \\ Sección de Histoquímica, División de Patología, Departamento de Investigación Cientifica, \\ Instituto Mexicano del Seguro Social, México, D.F. México \\ (Received 25th October 1971, accepted 10th Fanuary 1972)
}

\begin{abstract}
Summary. Proteolytic activity was demonstrated around the acrosomes of intact sperm cells with a simple cytochemical method using a gelatin substrate. The proteolytic activity was localized to the acrosomal region of both rat and human spermatozoa. Not all sperm cells showed the same digestive capacity in each sample studied.
\end{abstract}

Rabbit sperm acrosomes have a denuding effect on the zona pellucida, as Srivastava, Adams \& Hartree (1965a, b) have demonstrated. This finding suggested that penetration of a spermatozoon through the zona pellucida is mediated, at least in part, by the presence of hydrolytic enzymes. Recently, Stambaugh \& Buckley (1969) found hyaluronidase and a 'trypsin-like' enzyme in acrosomal extracts of rabbit spermatozoa; apparently the proteolytic enzyme is mainly responsible for the ability to penetrate the zona pellucida in this species.

The localization of proteolytic activity in intact sperm cells was accomplished by Gaddum \& Blandau (1970), using an india-ink gelatin substrate method. The technique promised to be simple enough to allow further studies and even semiquantitative estimations of protease activity; however, in trying to repeat the method, we found that it gave inconstant results and obscured a great deal of the cytological details of the cells under study, nor was it possible to obtain clear-cut 'digestion halos' around the acrosomes, as illustrated in Gaddum \& Blandau's original publication. We therefore attempted to develop a method that could clearly show proteolytic activity against gelatin, without significantly obscuring cytological detail.

Human ejaculates and rat epididymal spermatozoa were used. The spermatozoa were washed twice in Hanks' solution with sodium bicarbonate $0.35 \mathrm{~g} / 1$ at a final $\mathrm{pH}$ of $7 \cdot 4$. The gelatin solution $(5 \%)$ was prepared in a Veronalacetate buffer at a different $\mathrm{pH}$ ranging from $7 \cdot 4$ to 9 . Washed spermatozoa were spread evenly on a glass slide; after $2 \mathrm{~min}$ at room temperature, smears were immersed once in the gelatin solution kept at about 28 to $30^{\circ} \mathrm{G}$; the slides were set in a vertical position for a few minutes to obtain a thin gelatin film. After blotting the bottom edge, the slides were allowed to gel in a horizontal position in a humid chamber at room temperature from 12 to $48 \mathrm{hr}$. After incubation, 
they were immersed in a Ponceau staining solution for $2 \mathrm{~min}$ for simultaneous fixing and staining. Preparations were air-dried and examined under a light microscope. Similar sets of slides were prepared, adding soybean trypsin inhibitor to the gelatin or prefixing the sperm cells in formalin for $15 \mathrm{~min}$.

Proteolytic activity was detected as clear 'halos' on a red background around the sperm acrosomes. The $\mathrm{pH}$ was critical to obtain good and constant results since human cells showed maximal activity at $\mathrm{pH} 8$ and rat spermatozoa at $\mathrm{pH}$ 9. The size and intensity of the halos were variable but mainly dependent on the time of incubation. Between 12 and $24 \mathrm{hr}$, both human and rat spermatozoa had diffuse halos around the head, with a markedly lucent point in the region of the acrosome (Pl. 1, Figs. 1 and 2). After $48 \mathrm{hr}$ incubation, the halo was well demarcated and larger in diameter; in human sperm cells, a complete digestion of the gelatin membrane was seen around some cells (Pl. 1, Fig. 3). Not all spermatozoa showed proteolytic activity and the circle of digestion round neighbouring cells might vary from a large circle around the head to a discrete periacrosomal area of digestion. Our counts reveal that approximately $60 \%$ of sperm cells are capable of digesting gelatin. In contrast, Gaddum \& Blandau (1970) reported that most sperm cells showed proteolytic activity. Their finding could be explained by the fact that, using the india-ink gelatin method, those cells without activity are not clearly seen through the dense, black background.

The thickness of the substrate film was important because in areas where the film was too thick, the periacrosomal halo was partially or totally obscured. Slides treated with soybean trypsin inhibitor or fixed previously in formalin did not have areas of digestion; however, when soybean inhibitor was used at a lower concentration or for a shorter time, the inhbitory effect suppressed the large periacrosomal circle but did not affect the small central area of digestion. For rat spermatozoa, the point of maximal digestion was localized at the convexity of the head (PI. 1, Fig. 4) and for human spermatozoa, at the very tip of the acrosome.

The precise localization of proteolytic activity diffusing radially from the acrosomes of both human and rat material is easily accomplished by this method. The preservation of cytological detail allows good morphological and biochemical correlation. Since not all spermatozoa have the same gelatin-digestion capacity, percentage counts of proteolytic activity for different sperm cell populations could be easily obtained.

\section{REFERENCES}

Gaddum, P. \& Blandau, J. R. (1970) Proteolytic reaction of mammalian spermatozoa on gelatin membranes. Science, N.Y. 170, 749.

Srivastava, P. N., Adams, G. E. \& Hartree, E. F. (1965a) Enzymatic action of lipoglycoprotein preparations from sperm-acrosomes on rabbit ova. Nature, Lond. 205, 498.

Srivastava, P. N., Adams, G. E. \& Hartree, E. F. (1965b) Enzymatic action of acrosomal preparations on the rabbit ovum in vitro. F. Reprod. Fert. 10,61.

Stambaugh, R. \& Buckley, J. (1969) Identification and subcellular localization of the enzymes effecting penetration of the zona pellucida by rabbit spermatozoa. F. Reprod. Fert. 19, 423. 
Pl..111: 1
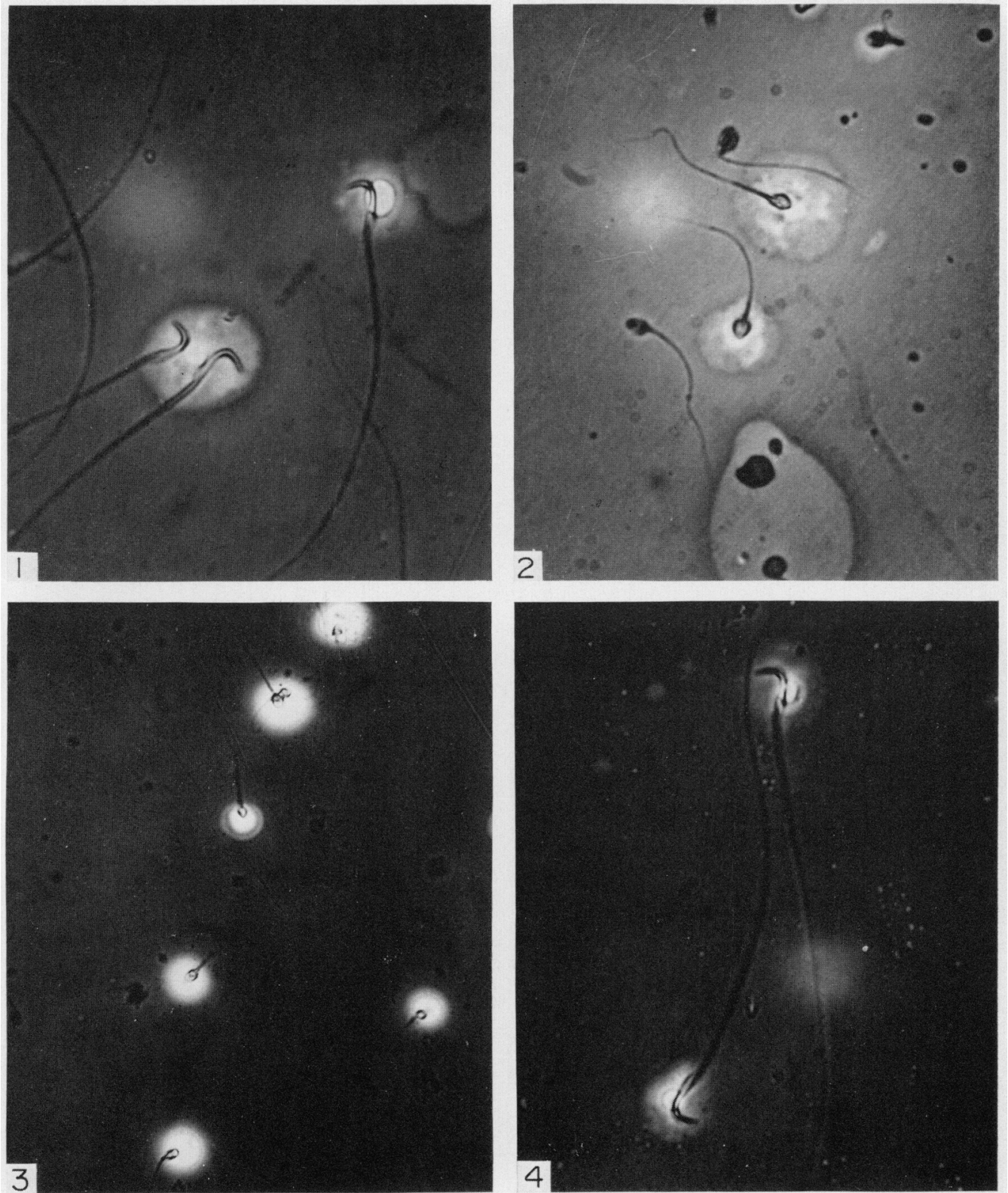

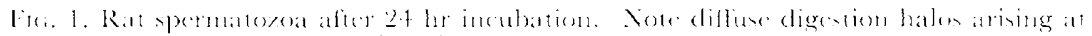

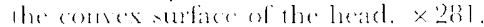

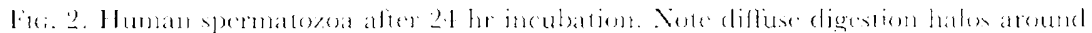

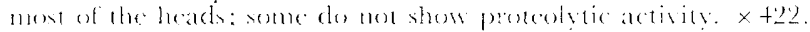

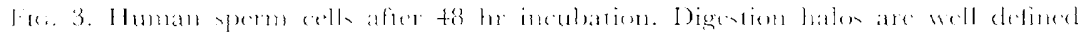
$x+2.2$.

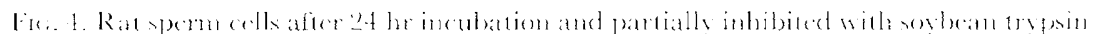



